\title{
Biology and Management of Yellow (Cyperus escuelentus) and Purple Nutsedge (C. rotundus) in Ornamental Crop Production and Landscapes ${ }^{1}$
}

\author{
Debalina Saha, Chris Marble, Nathan Boyd, and Shawn Steed ${ }^{2}$
}

\section{Species Description}

\section{Class}

Monocotyledonous plants

\section{Family}

Cyperaceae

\section{Other Common Names of Yellow Nutsedge}

Nut grass, chufa sedge, tiger nutsedge, and earth almond.

\section{Other Common Names of Purple Nutsedge}

Coco grass, java grass, nut grass, and red nutsedge.

\section{Life Span}

Both species are perennial plants.

\section{Habitat}

Both species are prevalent in lawns, cultivated areas, turf areas, landscape beds, gardens, fields, pastures, roadsides, edges of forests, grasslands, riverbanks, irrigation canal banks, and disturbed areas (Figures 1 and 2). Both species are very persistent once established.

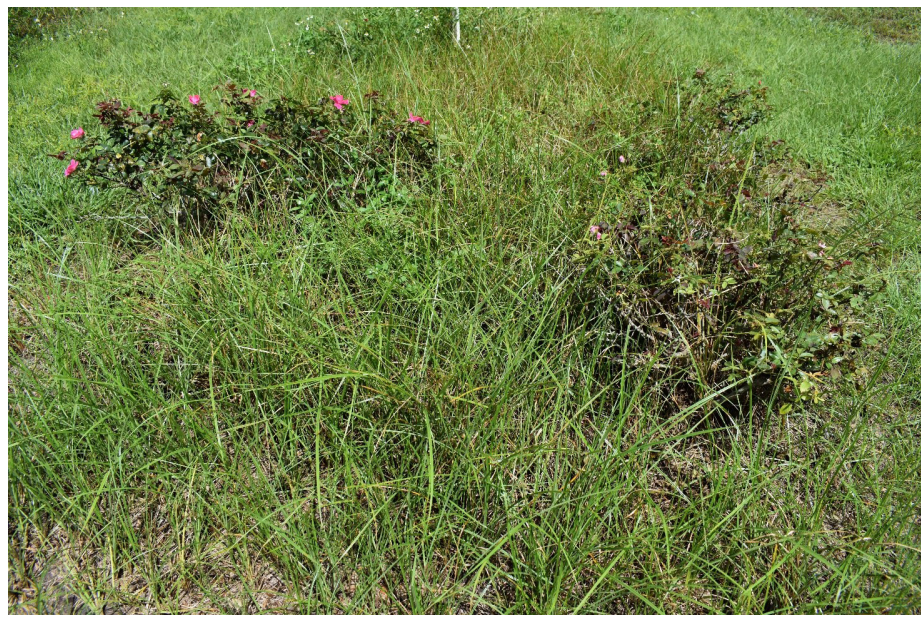

Figure 1. A rose garden heavily infested with both yellow and purple nutsedge.

Credits: Chris Marble, UF/IFAS

1. This document is ENH1305, one of a series of the Environmental Horticulture Department, UF/IFAS Extension. Original publication date March 2019. Visit the EDIS website at https://edis.ifas.ufl.edu for the currently supported version of this publication.

2. Debalina Saha, graduate research assistant; Chris Marble, assistant professor, Environmental Horticulture Department, Mid-Florida Research and Education Center, UF/IFAS Extension, Apopka, FL 32703; Nathan Boyd, associate professor, Horticultural Sciences Department, Gulf Coast REC, UF/IFAS Extension, Wimauma, FL 33598; and Shawn Steed, environmental horticulture production Extension agent, UF/IFAS Extension Hillsborough County, Seffner, FL 33584. 


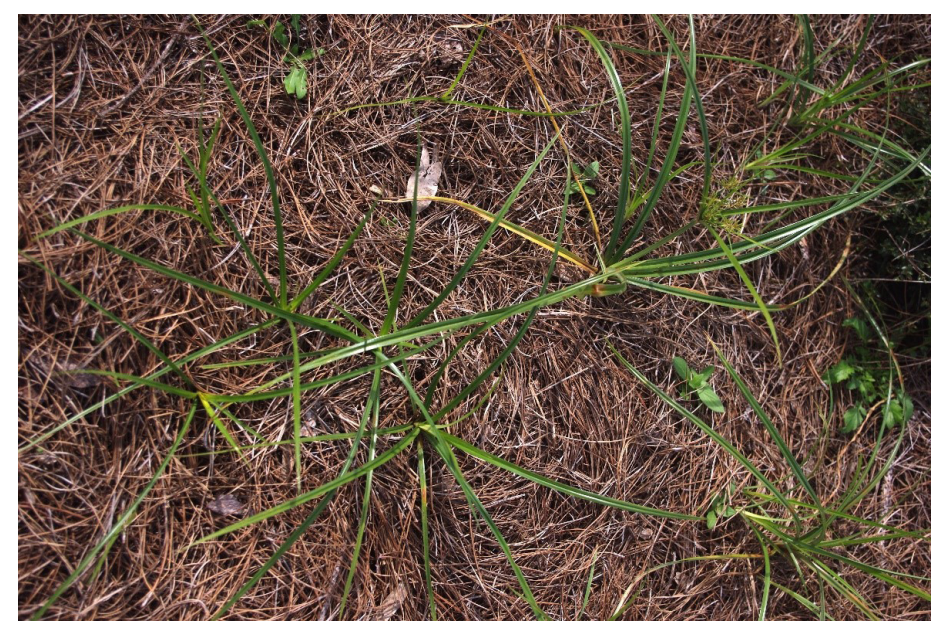

Figure 2. Yellow nutsedge growing in a landscape bed mulched with pine straw.

Credits: Chris Marble, UF/IFAS

\section{Distribution}

Cyperus esculentus (yellow nutsedge) is found worldwide in warm and temperate zones. In the western hemisphere, it grows from southern Canada to northern Argentina. This plant is common throughout most of the United States and is native to North America.

Cyperus rotundus (purple nutsedge) is thought to have originated in India by some authors, but others believe that its origin is more widespread and include northern and eastern Australia (Parsons and Cuthbertson 1992). Other authors believe it is native to the tropical and subtropical old world, mainly Eurasia and Africa (Govaerts 2007). This species has been officially recorded in 92 countries (Holm et al. 1977) but is thought to occur in all countries with tropical or subtropical climates. Purple nutsedge is not as tolerant as yellow nutsedge to colder weather. In the United States, purple nutsedge is found primarily from Virginia to central Texas (USDA-NRCS, Plant Guide) but has also naturalized in parts of Arizona, California, and Oregon (SWSS 1995; Westbrooks 1998).

\section{Growth Habit}

Both species have an upright growth habit and can reach up to 36 inches in height.

\section{Seedling}

Seedlings are very rare, as both species spread almost exclusively via rhizomes and tubers (Stoller \& Sweet 1987).

\section{Shoot}

The shoots of both yellow and purple nutsedge are triangular, borne individually from a tuber or basal bulb. Leaves arise from a central triangular stem and are three-ranked, or arranged in sets of three from the base, as well as Vshaped in the cross-section. The leaves in both yellow and purple nutsedge are thicker and stiffer than most grasses.

Yellow nutsedge leaves are 0.5 inches wide and 12 to 35 inches long. They are yellow-green, smooth, and shiny or waxy on the upper surface with long attenuated tips (Figure 3). Leaf blades of purple nutsedge are green, 0.2 to 0.5 inches wide, have a prominent midvein, and abruptly taper to a tip (Bryson and DeFelice 2009) (Figure 3). Purple nutsedge usually has shoots that are darker green when compared to yellow nutsedge.

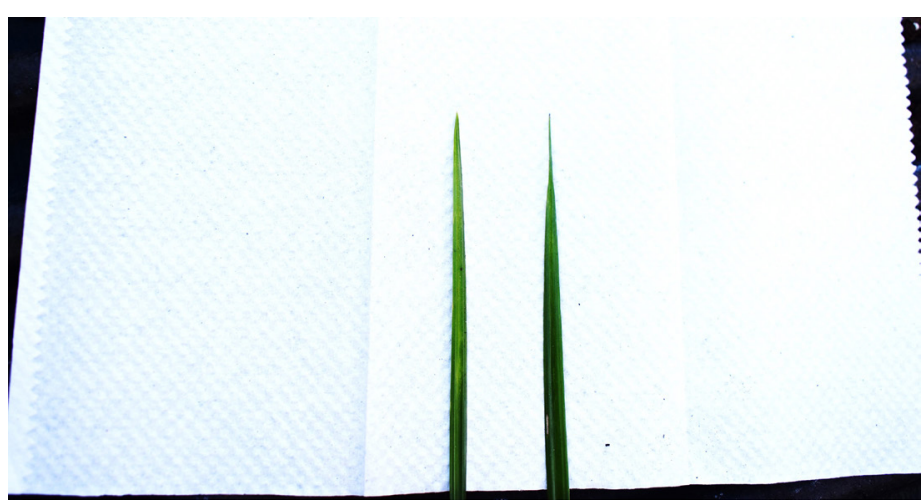

Figure 3. Leaf tips of purple nutsedge (left) and yellow nutsedge (right). Note how the leaf tip of purple nutsedge abruptly tapers at the tip, whereas yellow nutsedge has long attenuated tips. Credits: Chris Marble, UF/IFAS

\section{Roots, Rhizomes, Tubers, and Bulbs}

Both species produce deep fibrous roots, rhizomes, and distinct tubers. Tubers are produced on rhizomes, or underground stems. Buds on the tubers sprout and grow to form new plants and eventually form patches up to 10 feet or more in diameter (UC-IPM 2017). Yellow nutsedge tubers grow at the ends of rhizomes, are mostly round, hard, smooth, have scales when immature, are 0.1 to 0.6 inches diameter, and brown to black in color. Purple nutsedge tubers grow in chains along the rhizomes; they are round to oblong and often irregular in shape, are 0.1 to 1.0 inches long by about 0.3 inches in diameter, covered with red to brown papery scales, and have roots (Sholedice and Renz 2006). 


\section{Inflorescence}

The inflorescence (flowers) of yellow nutsedge consists of an umbel (a cluster of flowers originating from a central point) of spikes distributed throughout stalks of unequal length (1-3 inches), are yellow-brown, golden, or straw colored, and are supported by leaf-like bracts as long or longer than the spikes (Bryson and DeFelice 2009) (Figure 4).

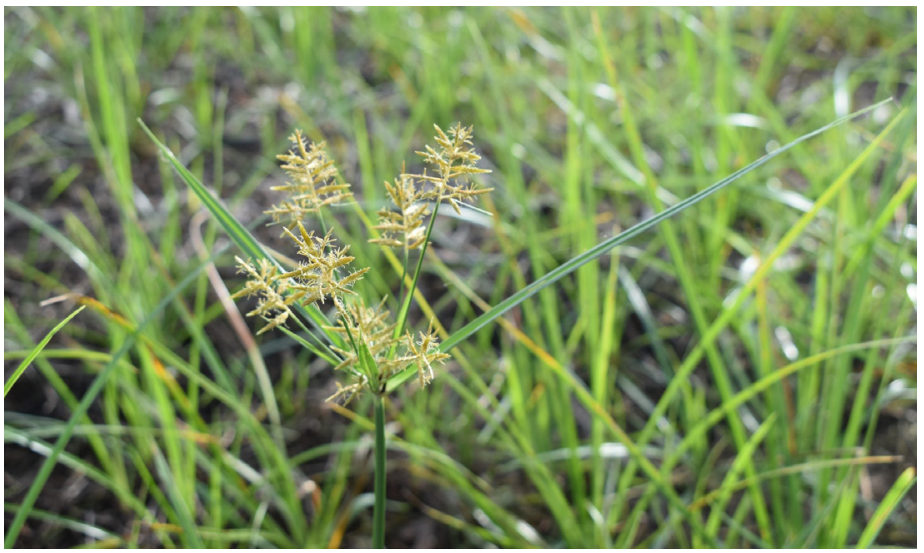

Figure 4. Yellow nutsedge inflorescence.

Credits: Annette Chandler, UF/IFAS

Within the continental United States, the inflorescence of purple nutsedge is umbel-like and contains unequally stalked spikes. The spikes are reddish-purple or reddishbrown in color (Wills 1998) (Figure 5).

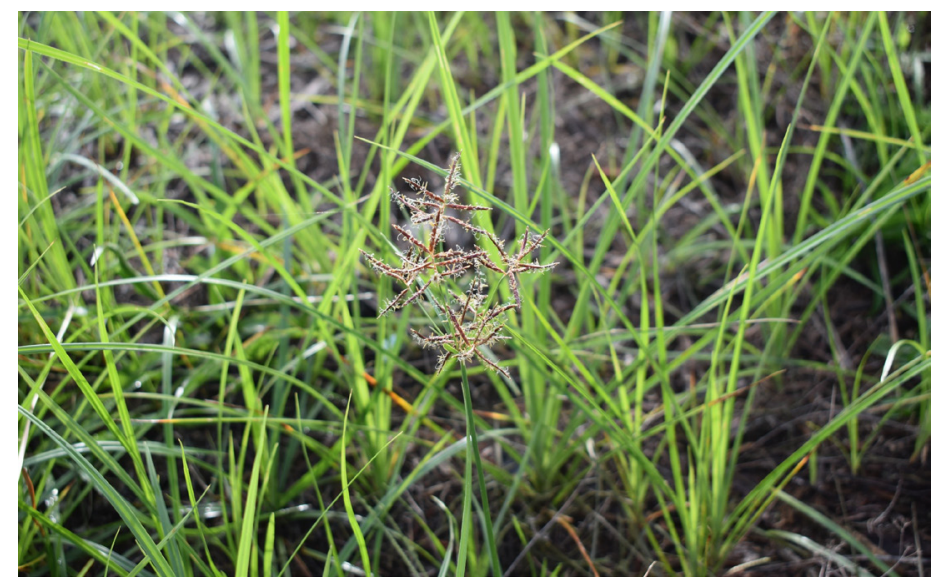

Figure 5. Purple nutsedge inflorescence.

Credits: Annette Chandler, UF/IFAS

\section{Fruit and Seeds}

Yellow nutsedge has tiny, single-seeded fruit (achenes) that are triangular in cross-section, blunt-headed, and yellowish-brown in color. Purple nutsedge does not typically produce seeds in the United States (UC-IPM 2017). Reproduction by seed is typically not a concern for either species as seed production and viability is low.

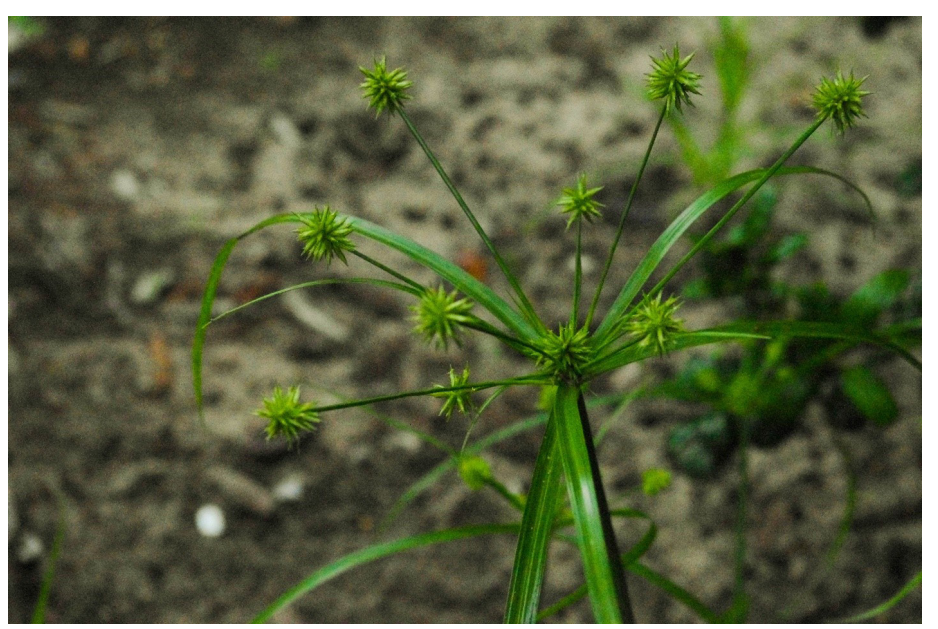

Figure 6. Globe sedge (Cyperus croceus) is often mistaken as yellow nutsedge.

Credits: Annette Chandler, UF/IFAS

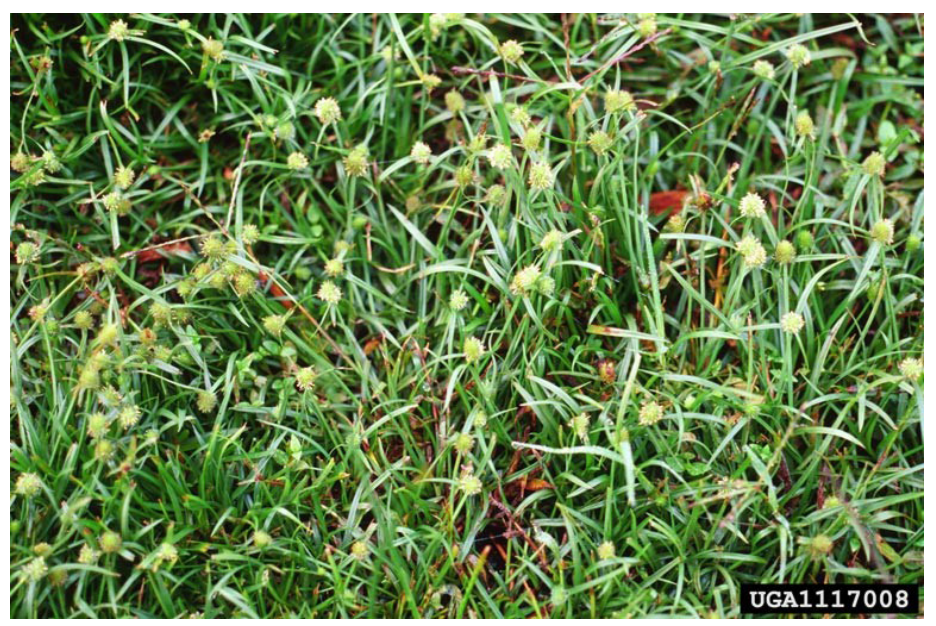

Figure 7. Kyllinga (Kyllinga brevifolia) is another sedge species that is often confused with nutsedge.

Credits: Charles T. Bryson, USDA-ARS bugwood.org

\section{Similar Species}

Yellow and purple nutsedge are very similar in appearance when young. The easiest way to identify which species is present is by examining the leaf tips (Figure 3), tubers, and root structures, and by examining the inflorescence if it is present (Figures 4-5). Other sedge species such as globe sedge (Cyperus croceus) (Figure 6) and kyllinga (Kyllinga spp.) (Figure 7) can be distinguished from yellow and purple nutsedge by examining the infloresence.

\section{Plant Biology}

Both species are perennial and grow most prolifically during the summer months but can emerge and grow in all seasons in Florida. Nutsedges reproduce mostly by tubers. Tuber formation begins from 4 to 6 weeks after seedling emergence; however, the shoot can continue to grow while tubers are forming. A rhizome emerges from the tuber, which forms a basal bulb after growing towards the soil 
surface. From the basal bulbs, the shoot and fibrous roots emerge. Basal bulbs usually form within 3 inches of the soil surface, although purple nutsedge bulbs can occur at 4-8 inches deep in the soil (Hauser 1962). During one growing season, especially if irrigation or rainfall is abundant and competition from other plants is minimal, yellow and purge nutsedge can produce 4 to 12 million tubers per acre (Hauser 1962; Horowitz 1972; Tumbleson and Kommendahl 1961).

\section{Management}

\section{Physical and Cultural Control}

Use of organic mulch materials such as pinebark, pinestraw, or wood chips at typical 2-3 inch depths recommended in the landscape are not effective. Research has shown both nutsedge species can also eventually penetrate many landscape fabrics (Derr and Appleton 1989). Woven polypropylene weed mats used alone or in combination with mulch have shown the ability to suppress both species (Brosnan \& DeFrank 2008; Chase et al. 1999). These fabrics are durable and commonly used in nursery production for preventing weeds in production areas. In landscapes, these fabrics could be used as they allow air and water to pass through, although proper installation in existing landscapes is difficult, as the fabrics often must be cut and pieced together around existing vegetation, which increases the chances of weed penetration. Organic mulch such as pinebark will usually be applied on top of the weed mat in landscape situations for aesthetic purposes. Over time, this mulch will degrade and other organic matter (grass clippings, leaves, etc.) will be deposited on top of the fabric, providing a suitable environment for other weed species to begin growing through the mat. These fabrics will break down over time, and species such as nutsedge can begin to emerge through the mats. The added cost and difficulty of removing weeds in areas where weed mats have been installed should be considered prior to installation (Derr and Appleton 1989).

Hand weeding will remove shoots, but they will rapidly regrow if tubers are not removed. It is rare for either species to be found growing in nursery containers if clean potting soil is used. Often, several annual sedges that reproduce via seed are misidentified as yellow or purple nutsedge in these cases. Both nutsedge species can become problematic in containers where recycled soil is used or field soil, compost, or other contaminated amendments are incorporated into potting substrates. It is very difficult to remove either species from a container by hand weeding. Prevention by cleaning equipment and using weed-free and fresh, uncontaminated potting soil is the best course of action.

\section{Chemical Control}

Before applying chemical weed controls, be sure to consult the latest information on weed control. The 2017 Southeast Pest Management Guide may provide specific chemical recommendations for controlling weeds. Additionally, always be sure to read the label before application to ensure safety.

\section{Preemergence Control}

Preemergence herbicides, including dimethanamid-p (Tower ${ }^{\circledR}$ ) and pendimethalin + dimethanamid-p (FreeHand ${ }^{\circledR}$ ), can provide some suppression of yellow nutsedge. S-metolachlor (Pennant Magnum ${ }^{\circledR}$ ) can provide suppression of both yellow and purple nutsedge.

\section{Postemergence Control}

Postemergence herbicides, including sulfosulfuron (Certainty ${ }^{\circledR}$ ), imazaquin (Sceptor $\mathrm{T} / \mathrm{O}^{\circledR}$ ), sulfentrazone (Dismiss $^{\circledR}$ ), halosulfuron (SedgeHammer ${ }^{\circledR}$ or ProSedge), and glyphosate (RoundUp ${ }^{\circledR}$ ) are effective for controlling both yellow and purple nutsedge. Bentazon (Basagran ${ }^{\circledR} \mathrm{T} / \mathrm{O}$ ) can be applied for control of yellow nutsedge. While primarily utilized as postemergence herbicides, both halosulfuron and sulfentrazone provide some preemergence activity on nutsedge. A more complete list of postemergence herbicides labeled for use in and around ornamentals to control nutsedge is listed in Table 2. It is important to note these postemergence herbicides will be much more effective when weeds are small (2 to 3 fully formed leaves) and actively growing. Repeated applications may be needed depending upon nutsedge growth stage and density. See individual product labels for use rates and application instructions.

\section{References}

Bryson, C. T., and M. S. DeFelice. 2009. Weeds of the South. University of Georgia Press. 467 p.

Chase, C. A., T. R. Sinclair, and S. J. Locascio. 1999. "Effects of soil temperature and tuber depth on Cyperus spp. control." WeedSci. 47: 467-472.

Derr, J. F., and B. L. Appleton. 1989. "Weed control with landscape fabrics." J. Environ. Hort. 7: 129-133. 
Govaerts, R., and D. A. Simpson. 2007. World checklist of Cyperaceae. Kew Pub. Royal Botanic Gardens. 780 p.

Holm, L. G., D. L. Plucknett, J. V. Pancho, and J. P. Herberger. 1977. The world's worst weeds. University Press. 609.

Hauser, E. W. 1962. "Development of purple nutsedge under field conditions.” Weeds. 10: 315-321.

Horowitz, M. 1972. "Growth, tuber formation and spread of Cyperus rotundus L. from a single tuber." Weed Res. 12: 348-363.

Parsons, W. T., and E. G. Cuthbertson. 1992. Noxious weeds of Australia. Melbourne, Australia: Inkata Press. 698.

Patton, A. and D. Weisenberger. 2017. "Sedge control for turf professionals." https://www.extension.purdue.edu/ extmedia/ay/ay-338-w.pdf

Sholedice, F. and M. Renz. 2006. "Yellow and purple nutsedge: ornamental and turf guide." http://aces.nmsu. edu/ces/plantclinic/documents/nutsedges-w-12.pdf

Southern Weed Science Society (SWSS). 1995. Weeds of the United States. Compact disk for Windows ${ }^{\circledR} 3.1$ or Windows ${ }^{\circledR} 95$ or higher. 1508 W. University Avenue, Champaign, Illinois.

Tumbleson, M. E. and T. Kommedahl. 1961. "Reproductive potential of Cyperus esculentus by tubers." Weeds. 9: 646-653.

United States Department of Agriculture-Natural Resources Conservation Service (USDA-NRCS). 2017. "Plant Guide." https://plants.usda.gov/plantguide/pdf/pg_cyro.pdf

Westbrook, R. G. 1998. "Invasive plants: changing the landscape of America." https://digitalcommons.usu.edu/ govdocs/490.

Wilen, C. A. 2010. "Pest notes: Nutsedge." University of California Statewide Integrated Pest Management Program. http://www.ipm.ucdavis.edu/PMG/PESTNOTES/pn 7432.

html

Wills, D. G. 1998. "Comparison of purple nutsedge (Cyperus rotundus) from around the world." Weed Tech. 12: 491-503. 
Table 1. Preemergence herbicides labeled for use in ornamentals for suppression of nutsedge.

\begin{tabular}{|c|c|c|c|c|c|}
\hline Herbicide & $\begin{array}{c}\text { Example } \\
\text { Trade Name }\end{array}$ & $\begin{array}{c}\text { WSSA } \\
\text { Herbicide } \\
\text { Group }^{1}\end{array}$ & $\begin{array}{l}\text { Application } \\
\text { Method }^{2}\end{array}$ & Use Sites $^{3}$ & Notes $^{4}$ \\
\hline dimethenamid-P & Tower & 15 & Over-the-top & $\begin{array}{l}\text { container, field, } \\
\text { landscape }\end{array}$ & $\begin{array}{l}\text { Can provide suppression of yellow } \\
\text { nutsedge. }\end{array}$ \\
\hline $\begin{array}{l}\text { pendimethalin }+ \\
\text { dimethenamid- } \mathrm{P}\end{array}$ & FreeHand & $3+15$ & Over-the-top & $\begin{array}{l}\text { container, field, } \\
\text { landscape }\end{array}$ & $\begin{array}{l}\text { Can provide suppression of yellow } \\
\text { nutsedge }\end{array}$ \\
\hline S-metolachlor & $\begin{array}{l}\text { Pennant } \\
\text { Magnum }\end{array}$ & 15 & Over-the-top & $\begin{array}{l}\text { container, field, } \\
\text { landscape }\end{array}$ & $\begin{array}{l}\text { Can provide suppression of yellow } \\
\text { and purple nutsedge. }\end{array}$ \\
\hline \multicolumn{6}{|c|}{$\begin{array}{l}{ }^{1} \text { Herbicide groups are based according to primary sites of action and can be used to select herbicides that have differing sites of action (Weed } \\
\text { Technology 17: 605-619 [2003]). } \\
{ }^{2} \text { Over-the-top means this product can be applied over ornamental species listed on product labels. Read each product label for a complete lis } \\
\text { of application instructions and tolerant ornamental species. } \\
{ }^{3} \text { Use sites are a general guideline for where these products can be applied. Read the label carefully as certain precautions and } \\
\text { recommendations are listed for applications within each site. } \\
{ }^{4} \text { This section serves only as a general guideline. Applicators are required to read each product label before use in order to know proper rates, } \\
\text { application techniques, use sites, and tolerant ornamentals. }\end{array}$} \\
\hline
\end{tabular}

Table 2. Postemergence herbicides labeled for use in ornamentals for control of nutsedge.

\begin{tabular}{|l|l|c|l|l|l|}
\hline \multicolumn{1}{|c|}{ Herbicide } & $\begin{array}{c}\text { Example Trade } \\
\text { Name }\end{array}$ & $\begin{array}{c}\text { WSSA Herbicide } \\
\text { Group }\end{array}$ & $\begin{array}{l}\text { Application } \\
\text { Method }^{2}\end{array}$ & \multicolumn{1}{|c|}{ Use Sites $^{3}$} & \multicolumn{1}{|c|}{ Notes $^{4}$} \\
\hline bentazon & Basagran T/O & 6 & Over-the-top & field, landscape & $\begin{array}{l}\text { Offers control of yellow nutsedge. Only apply } \\
\text { over-the-top to listed species. }\end{array}$ \\
\hline glyphosate & many & 9 & Directed & $\begin{array}{l}\text { container, field, } \\
\text { landscape }\end{array}$ & $\begin{array}{l}\text { Offers control of both species. Do not contact } \\
\text { stems, foliage or any other part of ornamental } \\
\text { with spray. }\end{array}$ \\
\hline halosulfuron & $\begin{array}{l}\text { SedgeHammer, } \\
\text { Prosedge }\end{array}$ & 2 & Directed & field, landscape & $\begin{array}{l}\text { Offers control of both species. May provide some } \\
\text { preemergence activity. }\end{array}$ \\
\hline imazaquin & Sceptor T/O & 2 & Over-the-top & landscape & $\begin{array}{l}\text { Effective on purple and yellow nutsedge. Apply } \\
\text { as a directed application to ornamentals not } \\
\text { listed on label. }\end{array}$ \\
\hline sulfentrazone & Dismiss & 14 & Directed & $\begin{array}{l}\text { container, field, } \\
\text { landscape }\end{array}$ & $\begin{array}{l}\text { Only certain ornamentals are listed, see label. } \\
\text { May provide some preemergence activity. }\end{array}$ \\
\hline sulfosulfuron & Certainty & 2 & Over-the-top & field, landscape & $\begin{array}{l}\text { Controls both nutsedge species. Only certain } \\
\text { broadleaf ornamentals and ornamental grasses } \\
\text { are listed. See label for details. }\end{array}$ \\
\hline
\end{tabular}

${ }^{1}$ Herbicide groups are based according to primary sites of action and can be used to select herbicides that have differing sites of action (Weed Technology 17: 605-619 [2003]).

${ }^{2}$ Over-the-top means this product can be applied over ornamental species listed on product labels. Directed means this product should not come into contact with ornamental plant tissues. Read each product label for a complete list of application instructions and tolerant ornamental species.

${ }^{3}$ Use sites are a general guideline for where these products can be applied. Read the label carefully as certain precautions and recommendations are listed for applications within each site.

${ }^{4}$ This section serves only as a general guideline. Applicators are required to read each product label before use in order to know proper rates, application techniques, use sites, and tolerant ornamentals. 